\title{
Cell metabolomics to study the function mechanism of Cyperus rotundus L. on triple- negative breast cancer cells
}

\author{
Shuangshuang Ma ${ }^{1,2+}$, Fukai Wang ${ }^{1 \dagger}$, Caijuan Zhang ${ }^{3}$, Xinzhao Wang ${ }^{1}$, Xueyong Wang ${ }^{4 *}$ and Zhiyong Yu ${ }^{1 *}$
}

\begin{abstract}
Background: Triple-negative breast cancer (TNBC) is a kind of malignant tumor with higher recurrence and metastasis rate. According to historical records, the dry rhizomes Cyperus rotundus L. could be ground into powder and mixed with ginger juice and wine for external application for breast cancer. We studied the effect of the ethanol extract of Cyperus rotundus L. (EECR) on TNBC cells and found its' apoptosis-inducing effect with a doserelationship. But the function mechanism of EECR on TNBC is still mysterious. Hence, the present research aimed to detect its function mechanism at the small molecule level through ultra-high performance liquid chromatography coupled with quadrupole-time-of-flight mass spectrometry (UPLC-Q-TOF-MS/MS) metabolomics.

Methods: The CCK-8 assay and the Annexin V-FITC/PI assay were applied to test the effect of EECR on MDA-MB231 cells and MDA-MB 468 cells at various concentrations of 0, 200, 400, and $600 \mu \mathrm{g} / \mathrm{ml}$. UPLC-Q-TOF-MS/MS based metabolomics was used between the control group and the EECR treatment groups. Multivariate statistical analysis was used to visualize the apoptosis-inducing action of EECR and filtrate significantly changed metabolites.

Results: The apoptosis-inducing action was confirmed and forty-nine significantly changed metabolites (VIP $>1$, $p<0.05$, and $F C>1.2$ or $F C<0.8$ ) were identified after the interference of EECR. The level of significant differential metabolites between control group, middle dose group, and high dose group were compared and found that which supported the apoptosis-inducing action with dose-dependence.

Conclusion: By means of metabolism, we have detected the mechanism of EECR inducing apoptosis of TNBC cells at the level of small molecule metabolites and found that EECR impacted the energy metabolism of TNBC cells. In addition, we concluded that EECR induced apoptosis by breaking the balance between ATP-production and ATP-consumption: arresting the pathways of Carbohydrate metabolism such as Central carbon metabolism in cancer, aerobic glycolysis, and Amino sugar and nucleotide sugar metabolism, whereas accelerating the pathways of ATP-consumption including Amino Acids metabolism, Fatty acid metabolism, Riboflavin metabolism and Purine metabolism. Although further study is still needed, EECR has great potential in the clinical treatment of TNBC with fewer toxic and side effects.
\end{abstract}

Keywords: Cell metabolomics, Triple-negative breast cancer, Cyperus rotundus L., Aerobic glycolysis, UPLC-Q-TOF-MS/MS

\footnotetext{
*Correspondence: wxyph.d@163.com; drzhiyongyu@aliyun.com

†'Shuangshuang Ma and Fukai Wang contributed equally to this work.

${ }^{4}$ School of Chinese Materia Medical, Beijing University of Chinese Medicine,

No.11 North 3rd Ring East Road, Chao-Yang District, Beijing 100029, China

'Shandong Cancer Hospital and Institute, Shandong First Medical University

and Shandong Academy of Medical Sciences, No.440 jiyan road, Jinan

250017, Shandong, China

Full list of author information is available at the end of the article
}

\section{$\triangle B M C$}

(c) The Author(s). 2020 Open Access This article is licensed under a Creative Commons Attribution 4.0 International License, which permits use, sharing, adaptation, distribution and reproduction in any medium or format, as long as you give appropriate credit to the original author(s) and the source, provide a link to the Creative Commons licence, and indicate if changes were made. The images or other third party material in this article are included in the article's Creative Commons licence, unless indicated otherwise in a credit line to the material. If material is not included in the article's Creative Commons licence and your intended use is not permitted by statutory regulation or exceeds the permitted use, you will need to obtain permission directly from the copyright holder. To view a copy of this licence, visit http://creativecommons.org/licenses/by/4.0/. The Creative Commons Public Domain Dedication waiver (http://creativecommons.org/publicdomain/zero/1.0/) applies to the data made available in this article, unless otherwise stated in a credit line to the data. 


\section{Background}

According to WHO reports, breast cancer involving 2.09 million cases is the most common cancer in 2018 and seriously affects woman's health around the world. Although breast cancer has a high cure rate when detected early and treated according to best practices, triple-negative breast cancer (TNBC) is an exception due to its lack expression characteristic of estrogen receptor (ER), progesterone receptor (PR), and human epidermal growth factor receptor-2 (Her-2). Patients with TNBC have an increased likelihood of distant recurrence and death. In addition, they cannot be treated with endocrine therapy or Her-2 targeted therapies $[1,2]$. The severe side-effect of chemotherapy drugs is almost universal and obstructs the treatment of cancer. Along with an earlier age-of-onset and more probability of the 'triple-negative' phenotype, an effective drug with low toxicity is always in demand during the treatment of breast cancer [3-5].

The dry rhizomes of Cyperus rotundus L., also named Xiangfu in Chinese, have an application history of 1700 years in China and are mainly applied to treat gynecological diseases. According to ancient literature, Xiangfu could be ground into powder and mixed with ginger juice and wine for external application for breast cancer. Presently, the cytotoxic effect of Cyperus rotundus L. on breast cancer cell lines has been reported [6-9]. In our previous study, we identified 21 phytochemical compounds in the ethanol extract Cyperus rotundus L.(EECR) and found that EECR induced TNBC cell apoptosis which is reflected by the enhancement of ratio of the $\mathrm{Bax} / \mathrm{Bcl}-2$ [10]. Despite the distinct apoptosis-inducing action, the function mechanism of EECR on TNBC cells is still mysterious and needs further in-deep research.

Metabolites being free from the impacts of epigenetic regulation and post-translational modifications act as the direct form for their biochemical activity, and hence they more veritably reflect their phenotype [11]. UPLC-MS/ MS has the advantages of simple pretreatment, high sensitivity, and the remarkable capacity of detection and identification, so it can be applied for complex samples to collect as much as features [12]. Accompanied with the development of high-resolution mass spectrometer, it shows a major advantage for untargeted metabolomics and is widely applied to detect the specific metabolic changes of a biological system in responding to disease, infection, drugs, or toxins [13-18].

In this research, UPLC-Q-TOF-MS/MS based cell metabolomics combined with a serious of metabolomics software such as Human Metabolome Database (http:// www.hmdb.ca/), KEGG Database (https://www.kegg.jp/), MetaboAnalyst (https://www.metaboanalyst.ca/), and XCMS Online (https://xcmsonline.scripps.edu/), was used for the detection and identification of features of cell extraction. The multivariate statistical discriminate analysis was applied for searching significant differential metabolites of TNBC cell lines after the intervention of EECR. The student's T-test was adopted for explaining the changes of each metabolite at the status of low, medium and high concentrations. TNBC cell lines of MDA-MB-468 and MDA-MB-231 were used at the same treatment condition aiming to increase the credibility of the results.

Based on the above analysis and our previously researches, the main objective of this study was to detect the significantly changes of metabolites after the intervention of EECR, reveal the function mechanism of EECR on inducing apoptosis of TNBC cells at the level of small molecule metabolites, and explain the nature of its dose-dependent apoptosis-inducing character. And then, it could lay the research foundation for the further deep study of EECR and provide a guide for clinical application.

\section{Methods \\ Materials and chemicals}

The dry rhizomes of Cyperus rotundus L. were purchased from Anhui Xiehecheng Co., Ltd. (Bozhou, China); the ethanol extract of Cyperus rotundus L. was acquired referring to previous reporting method [10]; Dulbecco's modified Eagle's medium (DMEM), penicillin, and streptomycin were purchased from Nanjing KeyGen Biotech. Co. Ltd. (Jiangsu, China); Fetal bovine serum (FBS) and Phosphate-buffered saline (PBS) was purchased from Gibco Company (New York, U.S.A.); Dimethyl sulfoxide (DMSO) was purchased from Thermo Fisher Scientific (Massachusetts, U.S.A.); The Cell Counting Kit- 8 assay (CCK-8) was purchased from MedChemExpress (New Jersey, U.S.A.); Acetonitrile (liquid chromatogram grade) was purchased from Merck KGaA (Darmstadt, Germany); Formic acid was purchased from Honeywell Trading Co., Ltd. (Muskegon, USA).

\section{Mass spectrometry analysis of EECR}

The EECR had been analyzed by UPLC-Q-TOF MS/MS for quality control and 21 metabolites were listed in previous study. The detail information was shown in the article [10].

\section{Cell treatment and viability analysis}

Cell lines of MDA-MB-468 and MDA-MB-231 were obtained from the Cell Bank of Shanghai Institute of Cell Biology (Chinese Academy of Sciences) and cultured in the air with $5 \% \mathrm{CO}_{2}$ at $37^{\circ} \mathrm{C}$. The cells were grown in DMEM supplemented with $10 \%(\mathrm{v} / \mathrm{v}) \mathrm{FBS}$ and 100 units $/ \mathrm{mL}$ penicillin and streptomycin. $1 \times 10^{4}$ cells per well were seeded in 96-well plates and cultured for $24 \mathrm{~h}$. Subsequently, MDA-MB-468 cells and MDA-MB231 cells were respectively treated with EECR at various concentrations of $0,200,400$, and $600 \mu \mathrm{g} / \mathrm{ml}$. All cells 
were exposed to EECR with mentioned concentrations for another $24 \mathrm{~h}$. The cell viability was conducted according to the manufacturer's instruction of CCK-8 assay. The optical density (OD) was measured at 450 $\mathrm{nm}$.

\section{Flow cytometry}

For confirming the apoptosis induced by EECR, three concentrations of $\operatorname{EECR}(0,200$, and $400 \mu \mathrm{g} / \mathrm{ml})$ were chosen to treat MDA-MB-231 cell, however, three concentrations $(0,400$, and $600 \mu \mathrm{g} / \mathrm{ml})$ were selected for MDA-MB-468. Cells at the density of $1 \times 10^{4}$ cells/well were seeded in 6-well plates and cultured. Until grew over $75 \%$ of the bottom, the cells were exposed to EECR at mentioned above concentrations for $24 \mathrm{~h}$. The cells were collected by EDTA-free trypsin, centrifuged at 1000 rpm for $3 \mathrm{~min}$, and washed twice with cold PBS softly. Following the instructions, the cells were re-suspended at a density of $1 \times 10^{6}$ cells $/ \mathrm{ml}$. $100 \mu \mathrm{l}$ suspension was mixed with $5 \mu \mathrm{l}$ of Annexin V-FITC and $5 \mu \mathrm{l}$ of Propidium Iodide (PI), incubated at $4{ }^{\circ} \mathrm{C}$ for $30 \mathrm{~min}$ in the dark, and tested on the FACS Calibur (Becton Dickinson, USA).

\section{Cell pretreatment and metabolomics analysis}

MDA-MB-468 and MDA-MB-231 cells were pooled onto culture dishes $(5 \mathrm{~cm}$ in diameter) at a density of $1 \times 10^{7}$ cells per dish. After cultured for $24 \mathrm{~h}$, the culture mediums were replaced for new blank culture medium (Control group) or medium containing EECR at various concentrations (Treatment group), and training for another $24 \mathrm{~h}$. Three repeats were set each group. All cells were washed thrice with ice-cold PBS and quenched by liquid nitrogen. Using ice-cold methanol/water (80:20; v/ v) as the extraction solution, the cells were scraped with cell Scraper, transferred to pre-cooling centrifuge tubes, intermittently vortex for $3 \mathrm{~min}$, and centrifuged (14,000 $\mathrm{rpm}, 4^{\circ} \mathrm{C}$ ) for $5 \mathrm{~min}$. The supernatants were filtered with $0.22 \mu \mathrm{m}$ microfiltration membranes and moved to new tubes for metabolomics analysis. The quality control (QC) samples were earned by equally mixing each sample. At first, six QC samples were operated to detect the stability of the instrument, and one QC sample was run after every ten injections during all sequences.

The supernatants were separated on the $\mathrm{C} 18$ column $(2.1 \times 100 \mathrm{~mm}, 1.8 \mu \mathrm{m}$, Acquity UPLC HSS T3, USA $)$ at $40^{\circ} \mathrm{C}$ and a flow rate of $0.3 \mathrm{~mL} / \mathrm{min}$ by the UPLC system (Waters Acquity UPLC class, U.S.A.). The temperature of the sample plate was set at $8{ }^{\circ} \mathrm{C}$ and the injection volume was $5 \mu \mathrm{L}$. The mobile phase A was water with $0.1 \%$ formic acid and the mobile phase B was acetonitrile. The gradient elution was adopted as follows: $0-1$ min, 5\% B; 1-2 min, 5-25\% B; 2-7 min, 24-40\% B; 7$8.5 \mathrm{~min}, 40-95 \% \mathrm{~B} ; 8.5-13.5 \mathrm{~min}, 95 \% \mathrm{~B} ; 13.5-14 \mathrm{~min}$, 95-5\% B; $14-18 \mathrm{~min}, 5 \% \mathrm{~B}$. The mass spectrometry information was detected by Q-TOF mass spectrometer equipped with ESI interface (Bruker Impact $\mathrm{II}^{\mathrm{Tm}}$, Germany). Both positive and negative ion modes were used. Capillary voltages were $3500 \mathrm{~V}$ (in positive ion mode) and $3000 \mathrm{~V}$ (in negative ion mode), nebulizer pressure was $2.0 \mathrm{Bar}$, the flow of dry gas was $8.0 \mathrm{l} / \mathrm{min}$, and the temperature of dry gas was $200^{\circ} \mathrm{C}$. The mass range of full-scan was set from 50 to $1000 \mathrm{Da}$. Na formate correction fluid was used for ensuring accurate mass data.

\section{Data analysis}

After the calibration, the raw data was converted into mzXML data by Burker Compass DataAnalysis (Germany). Subsequently, the peak information of mass, retention time, and intensity $\left(>10^{4}\right)$ were exported in the form of .xls data through XCMS Online (https://xcmsonline.scripps.edu/). Multivariate statistical discriminate analysis, such as principal component analysis (PCA) and partial least squares discriminant analysis (PLS-DA), were carried out on SIMCA-P (version 13.0, Umetrics, Sweden). The PCA, an unsupervised pattern recognition method, was applied to observe the distribution of the initial data. The crossvalidated PLS-DA was used to screen the different metabolites between treatment and control groups (VIP $>1$ ), and the permutations plot was used for assessing the PLS-DA model. Fold Change (FC) expresses the ratio of peak area of metabolites in the treatment and control group, which is used for filtrating metabolites with more significant difference. Student's t-test and FC were employed for defining significantly difference $(p<0.05, \mathrm{FC}<0.8$ or $\mathrm{FC}>1.2)$.

\section{Result}

\section{The cytotoxicity analysis of EECR on TNBC cells}

The EECR remarkably inhibits the proliferation of MDA-MB-231 and MDA-MB-468 cells at every concentration mentioned. After the treatment of EECR, the cell viability was down-regulation and remarkably relevant to EECR's concentrations (Fig. $1 \mathrm{a}, \mathrm{b}$ ), which is consistent with our previous study. The $\mathrm{IC}_{50}$ of EECR on MDAMB 231 and MDA-MB 468 cell lines were $537.5 \mu \mathrm{g} / \mathrm{ml}$ and $773.3 \mu \mathrm{g} / \mathrm{ml}$ respectively. For maintaining the similar cell viability between these two cell lines during the stage of metabolism, we respectively chose the concentrations of $400 \mu \mathrm{g} / \mathrm{ml}$ and $600 \mu \mathrm{g} / \mathrm{ml}$ for detecting the EECR function mechanism on TNBC cells. In addition to explaining the reasons of dose-related apoptotic effects on TNBC cells, the EECR concentrations of 200 and $400 \mu \mathrm{g} / \mathrm{ml}$ were selected for the following researches in MDA-MB 231 cell line, while the concentrations of 400 and $600 \mu \mathrm{g} / \mathrm{ml}$ were chosen in MDA-MB 468 cell line. It was verified by flow cytometry that the EECR induced apoptosis of TNBC cells in a dose-dependent manner. As shown in Fig. 1, Q1 quadrant represents 


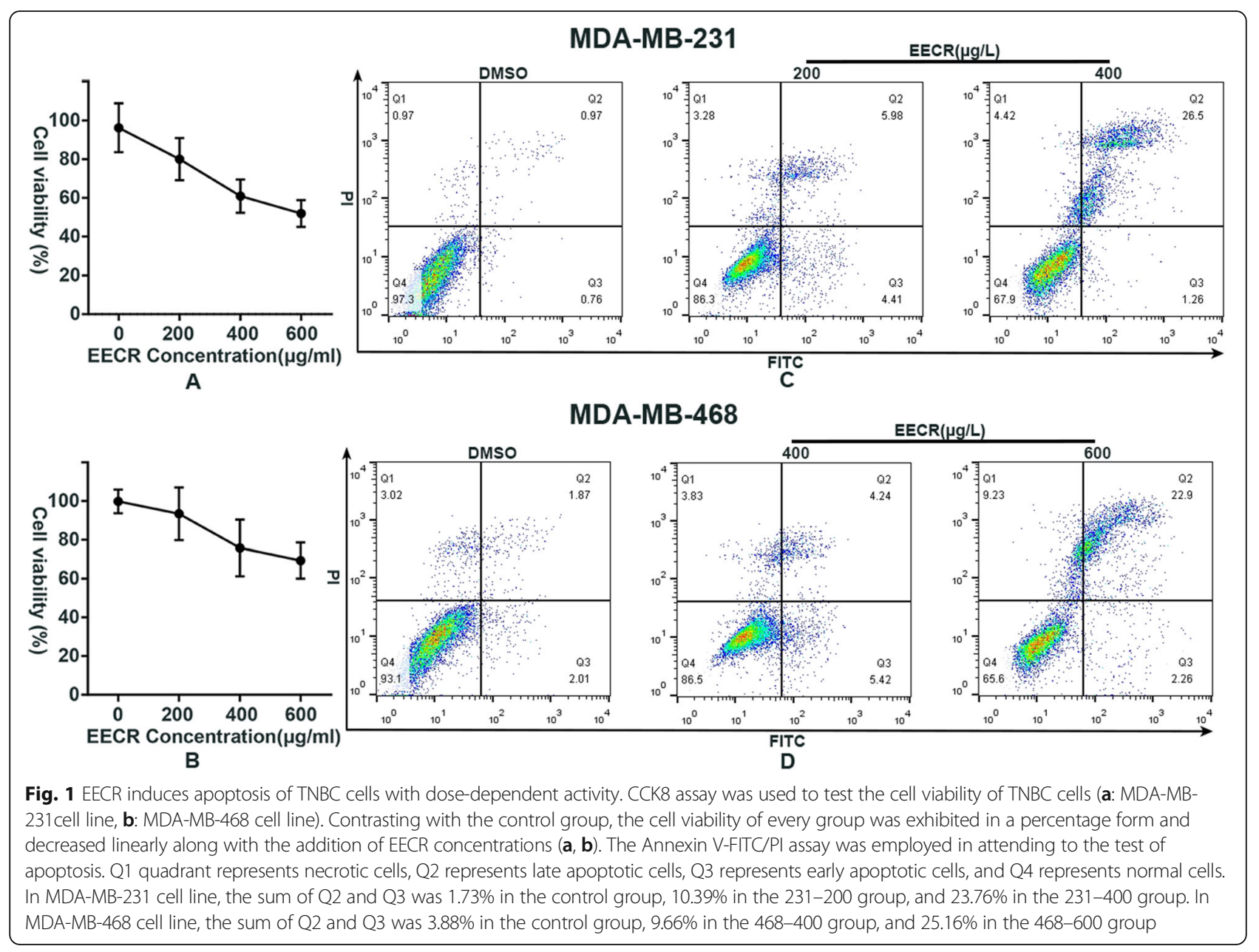

necrotic cells, Q2 represents late apoptotic cells, Q3 represents early apoptotic cells, and Q4 represents normal cells. The proportion of Q3 in the group of middle-dose of EECR was obviously more than the groups of control and high-dose, which meant that the early apoptotic cells were mainly detected at the middle concentration. While the proportion of Q2 of EECR treatment groups were both bigger than the control groups and kept the consistent relationship with the concentration of EECR which conformed with the result of cell viability analysis.

\section{Multivariate statistical analysis}

The base peak chromatograms (BPCs) of QCs were listed in Fig. 2 and the relative standard deviation (RSD) of every metabolite, at the range of $1.95 \sim 22.85 \%$ in negative mode and $1.33 \sim 22.30 \%$ in positive mode, was listed in Table 1. As listed, the real-time and peak intensity in this experiment both have good repeatability.

To visualize the overall changes of TNBC cells after the intervention of EECR, PCA was applied in the groups of MDA-MB-231 cell line (named: 231-0, 231200, 231-400) and MDA-MB-468 cell line (named: 468-
0, 468-400, 468-600) separately. Overall, the EECR treatment groups could be obviously differentiated from the control group, both in electron spray ionization positive $\left(\mathrm{ESI}^{+}\right)$mode (Fig. 3a, b) and negative $\left(\mathrm{ESI}^{-}\right)$mode (FigS1 A, B), which expressed that the intervention of EECR give rise to the changes of metabolites in TNBC cell lines. In combination with the result of the cell viability analysis, the changed metabolites were valuable for exploring the function mechanism of EECR on TNBC cells. In order to obtain these changed metabolites, groups of $231-0$ and $231-400$ were selected for PLS-DA, and groups of 468-0 and 468-600 did likewise. In $\mathrm{ESI}^{+}$mode, the groups of $231-0$ and $231-400$ got a clear separation with $\mathrm{R} 2 \mathrm{X}=0.389, \mathrm{R} 2 \mathrm{Y}=0.991$, and $\mathrm{Q} 2=0.959$ (Fig. 3c), the groups of $468-0$ and $468-600$ had a distinct separation with $\mathrm{R} 2 \mathrm{X}=0.443, \mathrm{R} 2 \mathrm{Y}=0.996$, and Q2 $=0.972$ (Fig. 3d); while in $\mathrm{ESI}^{-}$mode, the PLSDA score scatter plot showed an obvious discrimination between the group of 231-400 and 231-0 with R2X = $0.421, \mathrm{R} 2 \mathrm{Y}=0.994$, and $\mathrm{Q} 2=0.942(\mathrm{FigS1} \mathrm{C}$ ), so it is between the group of 468-0 and 468-600 with $\mathrm{R} 2 \mathrm{X}=$ 0.432, $\mathrm{R} 2 \mathrm{Y}=0.995$, and $\mathrm{Q} 2=0.962$ (FigS1 D). The 

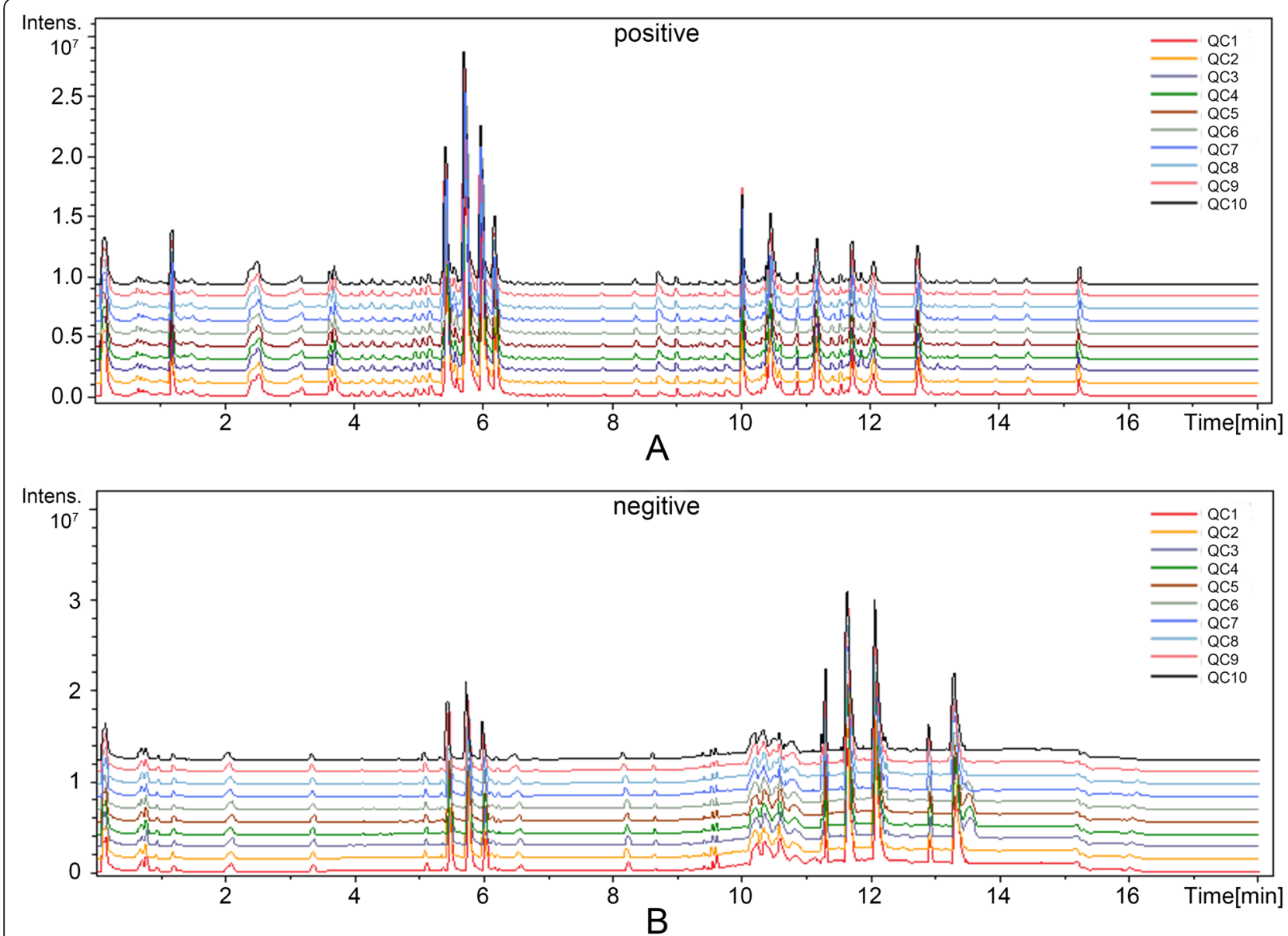

Fig. 2 Base peak chromatograms of QCs in ESI ${ }^{+/-}$mode. a shows the BPCs of QCs in positive mode; $\mathbf{b}$ displays the BPCs of QCs in negative mode. Both two have great repeatability

permutation plot was used to evaluate the PLS-DA model $(n=200)$ (Fig. 3e, f and FigS1 E, F), and showed no-overfitting in these models.

The identification of significantly differential metabolites Following the rules of VIP $>1, p<0.05$, and FC $>1.2$ (or $\mathrm{FC}<0.8$ ), a total of forty-nine features were identified as significantly differential metabolites. The detailed information of each metabolite was listed in Table 1. Among them, fifteen metabolites were found only via MDA-MB231 cell line, eleven were detected by means of MDAMB-468 cell line, and twenty-three were identified in both cell lines.

Except for Pantothenate, the other twenty-two metabolites have the same expression trend in content with statistically significant Fig. 4. Among those, the metabolites being significant up-regulation in both two cell lines included Cytosine, Inosine, Hippurate, (R)-5-Phosphomevalonate, Glutathione, L-Leucine, N-Acetyl-L-tyrosine ethyl ester, Riboflavin, Androstanedione, 1-Methylnicotinamide, L-alpha-Aminoadipate, (R)-4'-Phosphopantothenoyl-L- cysteine, Indole-3-acetate, Geranylgeranyl diphosphate, and 1-Palmitoylglycerophosphocholine. The metabolites being significant down-regulation in both two cell lines contained D-Glucose, L-Glutamate, L-Carnitine, Choline phosphate, beta-D-Fructose, N-Succinyl-L,L-2,6-diaminopimelate, and $\mathrm{N}$-Acetylneuraminate.

The function mechanism analysis of EECR on TNBC cells All significantly differential metabolites were searched against the KEGG database (https://www.kegg.jp/) for matching the metabolism pathway. The function mechanism of EECR on TNBC is mainly related to Amino acid metabolism, Riboflavin metabolism, Central carbon metabolism, Purine metabolism, and Amino Sugar and Nucleotide Sugar metabolism. The detailed changes in the main metabolism pathways were visualized in Fig. 5. As shown, metabolites taking part in Amino Sugar and Nucleotide Sugar metabolism and Arginine and Proline metabolism are reduced, while others are generally increased. 
Table 1 The detailed list of significantly differential metabolites identified in EECR treatment groups in both MDA-MB-231 cell line and MDA-MB-468 cell line

\begin{tabular}{|c|c|c|c|c|c|c|c|c|c|c|}
\hline ID & Compound Name & $\begin{array}{l}\text { KEGG } \\
\text { ID }\end{array}$ & $M / Z$ & $\begin{array}{l}\text { Real } \\
\text { time }\end{array}$ & Adducts & $\begin{array}{l}\text { ESI } \\
\text { mode }\end{array}$ & $\begin{array}{l}\text { Changes } \\
\text { in MDA- } \\
\text { MB-231 } \\
\text { cells line }\end{array}$ & $\begin{array}{l}\text { Changes } \\
\text { in MDA- } \\
\text { MB-468 } \\
\text { cells line }\end{array}$ & RSD & Relatd pathway \\
\hline 1 & L-Methionine S-oxide & C02989 & 165.0411 & 10.61 & $\mathrm{M}(\mathrm{C} 13)-\mathrm{H}[-]$ & neg & $\uparrow^{*}$ & - & $21.85 \%$ & $\begin{array}{l}\text { Cysteine and } \\
\text { methionine } \\
\text { metabolism }\end{array}$ \\
\hline 2 & Hexadecanoic acid & C00249 & 255.2333 & 12.09 & $\mathrm{M}-\mathrm{H}[-]$ & neg & $\uparrow^{*}$ & - & $10.12 \%$ & Fatty acid biosynthesis \\
\hline 3 & Scopoletin & C01752 & 232.0595 & 2.10 & $\mathrm{M}+\mathrm{ACN}-\mathrm{H}[-]$ & neg & $\uparrow^{* *}$ & - & $6.35 \%$ & $\begin{array}{l}\text { Phenylpropanoid } \\
\text { biosynthesis }\end{array}$ \\
\hline 4 & $\begin{array}{l}\text { 3,4-Dihydroxyphenyllactic } \\
\text { acid }\end{array}$ & C01207 & 163.0392 & 8.39 & $\mathrm{M}-\mathrm{H} 4 \mathrm{O} 2+\mathrm{H}[1+]$ & pos & $\uparrow^{* *}$ & - & $17.43 \%$ & / \\
\hline 5 & O-Butanoylcarnitine & C02862 & 232.1547 & 3.47 & $\mathrm{M}+\mathrm{H}[1+]$ & pos & $\uparrow^{* *}$ & - & $11.86 \%$ & / \\
\hline 6 & 4-Nitrophenol & C00870 & 138.0198 & 6.32 & $\mathrm{M}-\mathrm{H}[-]$ & neg & $\uparrow^{* *}$ & - & $10.59 \%$ & $\begin{array}{l}\text { Aminobenzoate } \\
\text { degradation }\end{array}$ \\
\hline 7 & Vaniline & C00755 & 151.0402 & 6.34 & $\mathrm{M}-\mathrm{H}[-]$ & neg & $\uparrow^{* *}$ & - & $3.45 \%$ & $\begin{array}{l}\text { Aminobenzoate } \\
\text { degradation }\end{array}$ \\
\hline 8 & L-Phenylalanine & C00079 & 164.0719 & 2.08 & $\mathrm{M}-\mathrm{H}[-]$ & neg & $\uparrow^{* *}$ & - & $1.95 \%$ & $\begin{array}{l}\text { Central carbon } \\
\text { metabolism in cancer/ } \\
\text { Phenylalanine } \\
\text { metabolism }\end{array}$ \\
\hline 9 & Octadecanoic acid & C01530 & 283.2645 & 13.31 & $\mathrm{M}-\mathrm{H}[-]$ & neg & $\uparrow^{* *}$ & - & $7.83 \%$ & Fatty acid biosynthesis \\
\hline 10 & 3-Dehydrosphinganine & C02934 & 282.2793 & 11.58 & $\mathrm{M}-\mathrm{H} 2 \mathrm{O}+\mathrm{H}[1+]$ & pos & $\uparrow^{* *}$ & - & $7.74 \%$ & $\begin{array}{l}\text { Sphingolipid } \\
\text { metabolism }\end{array}$ \\
\hline 11 & 2-Ethylhexyl phthalate & C03343 & 279.1593 & 13.43 & $\mathrm{M}+\mathrm{H}[1+], \mathrm{M}-\mathrm{H}[-]$ & $\begin{array}{l}\text { pos/ } \\
\text { neg }\end{array}$ & $\uparrow^{* *}$ & $\downarrow$ & $11.19 \%$ & / \\
\hline 12 & L-Homocarnosine & C00884 & 195.1229 & 3.23 & $\mathrm{M}-\mathrm{HCOOH}+\mathrm{H}[1+]$ & pos & $\uparrow^{* *}$ & $\downarrow$ & $13.60 \%$ & $\begin{array}{l}\text { Arginine and proline } \\
\text { metabolism }\end{array}$ \\
\hline 13 & Melatonin & C01598 & 269.0860 & 9.24 & $\mathrm{M}+\mathrm{Cl} 37[-]$ & neg & $\uparrow^{* *}$ & $\downarrow$ & $7.70 \%$ & $\begin{array}{l}\text { Tryptophan } \\
\text { metabolism }\end{array}$ \\
\hline 14 & beta-D-Galactose & C00962 & 219.0267 & 0.78 & $M+K[1+]$ & pos & $\downarrow^{* *}$ & - & $2.15 \%$ & / \\
\hline 15 & beta-L-Aspartylhydroxamate & C03124 & 226.9662 & 1.60 & $M+\operatorname{Br}[-]$ & neg & $\downarrow^{* *}$ & - & $19.55 \%$ & / \\
\hline 16 & Adenine & C00147 & 136.0620 & 1.24 & $\mathrm{M}+\mathrm{H}[1+]$ & pos & - & $\uparrow^{* *}$ & $8.19 \%$ & Purine metabolism \\
\hline 17 & Citric acid & C00158 & 191.0199 & 0.73 & $\mathrm{M}-\mathrm{H}[-], \mathrm{M}+\mathrm{Na}[+]$ & $\begin{array}{l}\text { neg/ } \\
\text { pos }\end{array}$ & - & $\uparrow^{* *}$ & $7.30 \%$ & $\begin{array}{l}\text { Central carbon } \\
\text { metabolism in cancer }\end{array}$ \\
\hline 18 & L-Tyrosine & C00082 & 182.0813 & 1.03 & $\mathrm{M}+\mathrm{H}[1+]$ & pos & - & $\uparrow^{* *}$ & $10.23 \%$ & $\begin{array}{l}\text { Central carbon } \\
\text { metabolism in cancer/ } \\
\text { Tyrosine metabolism }\end{array}$ \\
\hline 19 & 2-Phenylacetamide & C02505 & 136.0757 & 0.85 & $\mathrm{M}+\mathrm{H}[1+]$ & pos & - & $\uparrow^{* *}$ & $8.61 \%$ & $\begin{array}{l}\text { Phenylalanine } \\
\text { metabolism }\end{array}$ \\
\hline 20 & Riboflavin-5-phosphate & C00061 & 455.0977 & 4.15 & $\mathrm{M}-\mathrm{H}[-]$ & neg & - & $\uparrow^{* *}$ & $3.88 \%$ & Riboflavin metabolism \\
\hline 21 & Flavin adenine dinucleotide & C00016 & 784.1504 & 3.81 & $\mathrm{M}-\mathrm{H}[-]$ & neg & - & $\uparrow^{* *}$ & $6.87 \%$ & Riboflavin metabolism \\
\hline 22 & 4-Hydroxybenzoate & C00156 & 137.0246 & 3.90 & $\mathrm{M}-\mathrm{H}[-]$ & neg & - & $\downarrow^{*}$ & $4.74 \%$ & Benzoate degradation \\
\hline 23 & Methyl oleate & C03425 & 295.2647 & 12.80 & $\mathrm{M}-\mathrm{H}[-]$ & neg & - & $\downarrow^{* *}$ & $16.74 \%$ & / \\
\hline 24 & UDP-N-acetylglucosamine & C00043 & 606.0748 & 0.71 & $\mathrm{M}-\mathrm{H}[-]$ & neg & - & $\downarrow^{* *}$ & $4.06 \%$ & $\begin{array}{l}\text { Amino sugar and } \\
\text { nucleotide sugar } \\
\text { metabolism }\end{array}$ \\
\hline 25 & S-Adenosylmethioninamine & C01137 & 355.1531 & 12.07 & $M[1+]$ & pos & - & $\downarrow^{* *}$ & $11.94 \%$ & $\begin{array}{l}\text { Cysteine and } \\
\text { methionine } \\
\text { metabolism/Arginine } \\
\text { and proline } \\
\text { metabolism }\end{array}$ \\
\hline 26 & Adenosine & C00212 & 266.0900 & 2.90 & $\begin{array}{l}\mathrm{M}-\mathrm{H}[-], \mathrm{M}+\mathrm{Cl}[-] \\
\mathrm{M}+\mathrm{H}[1+]\end{array}$ & $\begin{array}{l}\text { neg/ } \\
\text { pos }\end{array}$ & - & $\downarrow^{* *}$ & $8.66 \%$ & Purine metabolism \\
\hline
\end{tabular}


Table 1 The detailed list of significantly differential metabolites identified in EECR treatment groups in both MDA-MB-231 cell line and MDA-MB-468 cell line (Continued)

\begin{tabular}{|c|c|c|c|c|c|c|c|c|c|c|}
\hline ID & Compound Name & $\begin{array}{l}\text { KEGG } \\
\text { ID }\end{array}$ & $M / Z$ & $\begin{array}{l}\text { Real } \\
\text { time }\end{array}$ & Adducts & $\begin{array}{l}\text { ESI } \\
\text { mode }\end{array}$ & $\begin{array}{l}\text { Changes } \\
\text { in MDA- } \\
\text { MB- } 231 \\
\text { cells line }\end{array}$ & $\begin{array}{l}\text { Changes } \\
\text { in MDA- } \\
\text { MB-468 } \\
\text { cells line }\end{array}$ & RSD & Relatd pathway \\
\hline 27 & (R)-5-Phosphomevalonate & C01107 & 212.0202 & 8.39 & $\mathrm{M}-\mathrm{NH} 3+\mathrm{H}[1+]$ & pos & $\uparrow^{*}$ & $\uparrow^{* *}$ & $3.13 \%$ & / \\
\hline 28 & Hippurate & C01586 & 178.0512 & 3.42 & $\mathrm{M}-\mathrm{H}[-]$ & neg & $\uparrow^{* *}$ & $\uparrow^{*}$ & $12.38 \%$ & $\begin{array}{l}\text { Phenylalanine } \\
\text { metabolism }\end{array}$ \\
\hline 29 & Glutathione & C00051 & 308.0911 & 1.24 & $\mathrm{M}+\mathrm{H}[1+]$ & pos & $\uparrow^{* *}$ & $\uparrow^{* *}$ & $1.33 \%$ & $\begin{array}{l}\text { Cysteine and } \\
\text { methionine } \\
\text { metabolism }\end{array}$ \\
\hline 30 & Riboflavin & C00255 & 377.1459 & 4.19 & $\mathrm{M}+\mathrm{H}[1+]$ & pos & $\uparrow^{* *}$ & $\uparrow^{* *}$ & $3.20 \%$ & $\begin{array}{l}\text { Riboflavin } \\
\text { metabolism }\end{array}$ \\
\hline 31 & Androstanedione & C00674 & 307.2271 & 11.33 & $\mathrm{M}+\mathrm{H} 2 \mathrm{O}+\mathrm{H}[1+]$ & pos & $\uparrow^{* *}$ & $\uparrow^{* *}$ & $5.41 \%$ & $\begin{array}{l}\text { Steroid hormone } \\
\text { biosynthesis }\end{array}$ \\
\hline 32 & N-Acetyl-L-tyrosine ethyl ester & C01657 & 208.1336 & 9.03 & $\mathrm{M}-\mathrm{CO} 2+\mathrm{H}[1+]$ & pos & $\uparrow^{* *}$ & $\uparrow^{* *}$ & $6.26 \%$ & / \\
\hline 33 & Geranylgeranyl diphosphate & C00353 & 383.2098 & 10.90 & $\mathrm{M}-\mathrm{HCOONa}+\mathrm{H}[1+]$ & pos & $\uparrow^{* *}$ & $\uparrow^{* *}$ & $2.17 \%$ & / \\
\hline 34 & $\begin{array}{l}\text { 1- } \\
\text { Palmitoylglycerophosphocholine }\end{array}$ & C04102 & 496.3401 & 10.36 & $M[1+]$ & pos & $\uparrow^{* *}$ & $\uparrow^{* *}$ & $5.38 \%$ & / \\
\hline 35 & L-Leucine & C00123 & 132.1019 & 0.89 & $\mathrm{M}+\mathrm{H}[1+]$ & pos & $\uparrow^{* *}$ & $\uparrow^{* *}$ & $5.00 \%$ & $\begin{array}{l}\text { Central carbon } \\
\text { metabolism in cancer }\end{array}$ \\
\hline 36 & L-alpha-Aminoadipate & C00956 & 116.0706 & 0.82 & $\mathrm{M}-\mathrm{HCOOH}+\mathrm{H}[1+]$ & pos & $\uparrow^{* *}$ & $\uparrow^{* *}$ & $1.56 \%$ & Lysine degradation \\
\hline 37 & 1-Methylnicotinamide & C02918 & 137.0710 & 0.79 & $M[1+]$ & pos & $\uparrow^{* *}$ & $\uparrow^{* *}$ & $1.48 \%$ & $\begin{array}{l}\text { Nicotinate and } \\
\text { nicotinamide } \\
\text { metabolism }\end{array}$ \\
\hline 38 & $\begin{array}{l}\text { (R)-4'-Phosphopantothenoyl-L- } \\
\text { cysteine }\end{array}$ & C04352 & 335.1067 & 7.89 & $\begin{array}{l}\mathrm{M}-\mathrm{HCOONa}+\mathrm{H}[1+] \\
\mathrm{M}-\mathrm{HCOOH}+\mathrm{H}[1+]\end{array}$ & pos & $\uparrow^{* *}$ & $\uparrow^{* * *}$ & $4.32 \%$ & $\begin{array}{l}\text { Pantothenate and } \\
\text { CoA biosynthesis }\end{array}$ \\
\hline 39 & Inosine & C00294 & 249.0632 & 3.00 & $\mathrm{M}-\mathrm{H} 2 \mathrm{O}-\mathrm{H}[-]$ & neg & $\uparrow^{* *}$ & $\uparrow^{* *}$ & $5.46 \%$ & Purine metabolism \\
\hline 40 & Cytosine & C00380 & 146.9832 & 0.82 & $\mathrm{M}+\mathrm{K}-2 \mathrm{H}[-]$ & neg & $\uparrow^{* *}$ & $\uparrow^{* *}$ & $3.88 \%$ & Pyrimidine metabolism \\
\hline 41 & Indole-3-acetate & C00954 & 176.0710 & 7.89 & $\mathrm{M}+\mathrm{H}[1+]$ & pos & $\uparrow^{* *}$ & $\uparrow^{* *}$ & $3.36 \%$ & Tryptophan metabolism \\
\hline 42 & Pantothenate & C00864 & 202.1077 & 3.22 & $\begin{array}{l}\mathrm{M}-\mathrm{H} 2 \mathrm{O}+\mathrm{H}[1+], \mathrm{M}+ \\
\mathrm{H}[1+]\end{array}$ & pos & $\uparrow^{* *}$ & $\downarrow^{* *}$ & $20.56 \%$ & $\begin{array}{l}\text { Pantothenate and } \\
\text { CoA biosynthesis }\end{array}$ \\
\hline 43 & L-Carnitine & C00318 & 162.1125 & 0.80 & $\mathrm{M}-\mathrm{H}[-]$ & pos & $\downarrow^{* *}$ & $\downarrow^{* *}$ & $2.31 \%$ & / \\
\hline 44 & Choline phosphate & C00588 & 184.0734 & 0.79 & $M+$ & pos & $\downarrow^{* *}$ & $\downarrow^{* *}$ & $4.06 \%$ & / \\
\hline 45 & beta-D-Fructose & C02336 & 203.0527 & 0.80 & $\mathrm{M}+\mathrm{Na}[1+]$ & pos & $\downarrow^{* *}$ & $\downarrow^{* *}$ & $3.18 \%$ & $\begin{array}{l}\text { Amino sugar and } \\
\text { nucleotide sugar } \\
\text { metabolism }\end{array}$ \\
\hline 46 & $\mathrm{~N}$-Acetylneuraminate & C00270 & 292.1031 & 3.52 & $\mathrm{M}-\mathrm{H} 2 \mathrm{O}+\mathrm{H}[1+]$ & pos & $\downarrow^{* *}$ & $\downarrow^{* *}$ & $2.94 \%$ & $\begin{array}{l}\text { Amino sugar and } \\
\text { nucleotide sugar } \\
\text { metabolism }\end{array}$ \\
\hline 47 & D-Glucose & C00031 & 215.0330 & 0.80 & $\mathrm{M}+\mathrm{Cl}[-]$ & neg & $\downarrow^{* *}$ & $\downarrow^{* *}$ & $4.13 \%$ & $\begin{array}{l}\text { Central carbon } \\
\text { metabolism in cancer }\end{array}$ \\
\hline 48 & L-Glutamate & C00025 & 146.0460 & 0.74 & $\mathrm{M}-\mathrm{H}[-]$ & neg & $\downarrow^{* *}$ & $\downarrow^{* *}$ & $2.67 \%$ & $\begin{array}{l}\text { Central carbon } \\
\text { metabolism in cancer }\end{array}$ \\
\hline 49 & $\begin{array}{l}\text { N-Succinyl-L,L-2,6- } \\
\text { diaminopimelate }\end{array}$ & C04421 & 274.0926 & 3.52 & $\mathrm{M}-\mathrm{NH} 3+\mathrm{H}[1+]$ & pos & $\downarrow^{* *}$ & $\downarrow^{* *}$ & $3.37 \%$ & Lysine biosynthesis \\
\hline
\end{tabular}

$\uparrow$ means that the level of the corresponding metabolite is higher in EECR treatment group compared to the control group; $\downarrow$ means that the level of the metabolite is lower in EECR treatment group compared to the control group. - indicates that no distinct change between the EECR treatment groups and the control group is found. / represents that the pathway what the metabolite participates in is unclear. ${ }^{*} p<0.05$; ${ }^{* *} p<0.01$

\section{Discussion}

The cytotoxicity of EECR on TNBC cells has been reported and is confirmed once again $[7,10]$. This research employed cell metabolism to reveal the function mechanism of EECR on TNBC cells at the level of small molecular metabolites and identified forty-nine significant differential metabolites. Both in MDA-MB 231 cell line and MDA-MB 468 cell line, the level of most metabolites mentioned above showed the same variation trend between control group, middle dose group, and high dose group. As shown in Fig. 


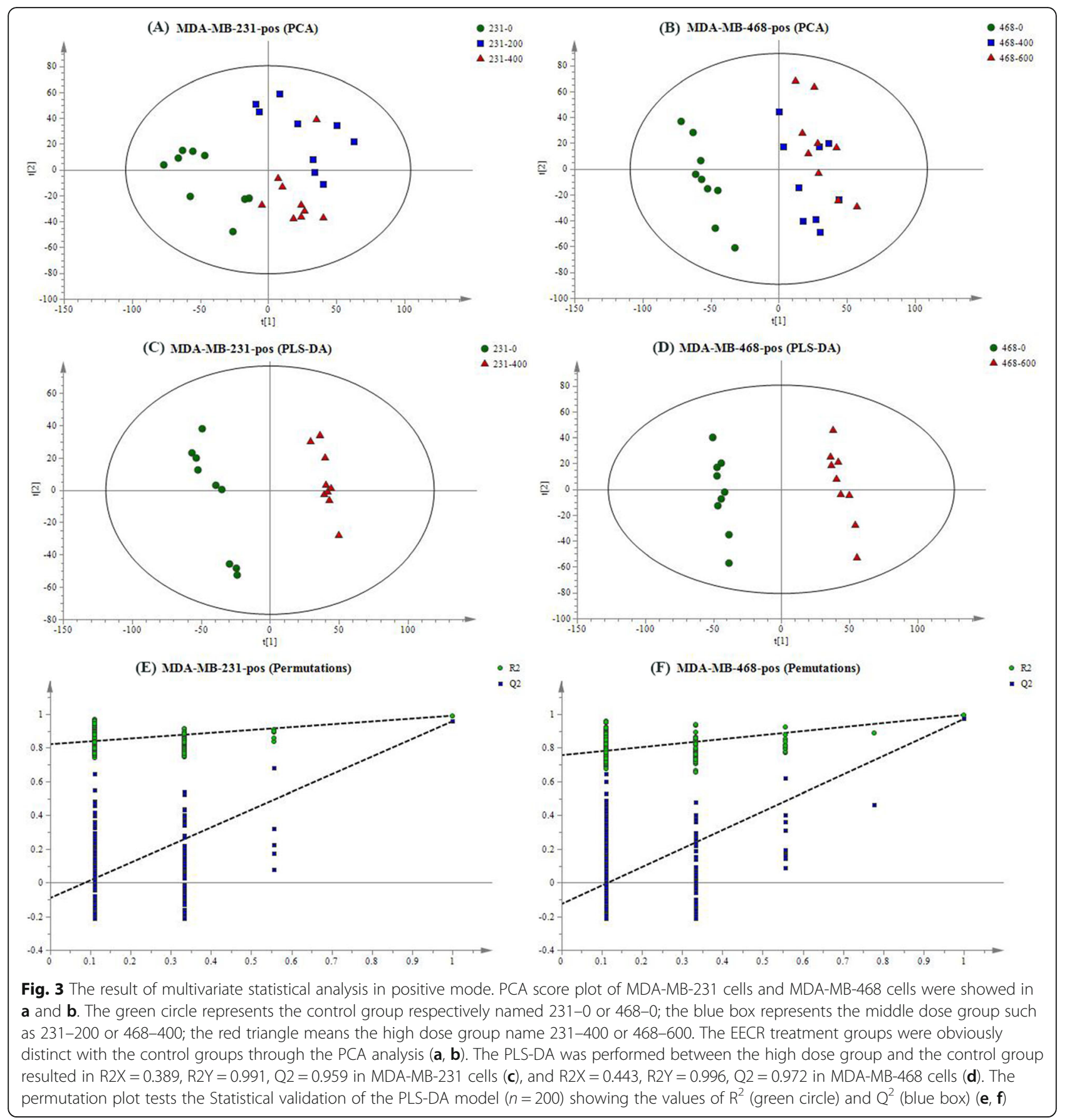

4, it explained the reason why the EECR induced apoptosis on TNBC cells with dose-dependent manner and confirmed the value of these metabolites in the process of EECR inducing TNBC apoptosis.

By searching for KEGG database, these significant differential metabolites were mapped to such metabolic pathways including Central Carbon metabolism in cancer, Glycolysis, Amino Sugar and Nucleotide Sugar metabolism, Phenylalanine metabolism, Arginine and
Proline metabolism, Cysteine and Methionine metabolism, Tryptophan metabolism, Lysine degradation, Purine metabolism, Riboflavin metabolism, Pantothenate and CoA biosynthesis, and Fatty Acid biosynthesis. To sum up, EECR induced TNBC cells apoptosis mainly through five major types of metabolism involving Amino Acid metabolism, Carbohydrate metabolism, Nucleotide metabolism, Lipid metabolism, and metabolism of Cofactors and Vitamins. 


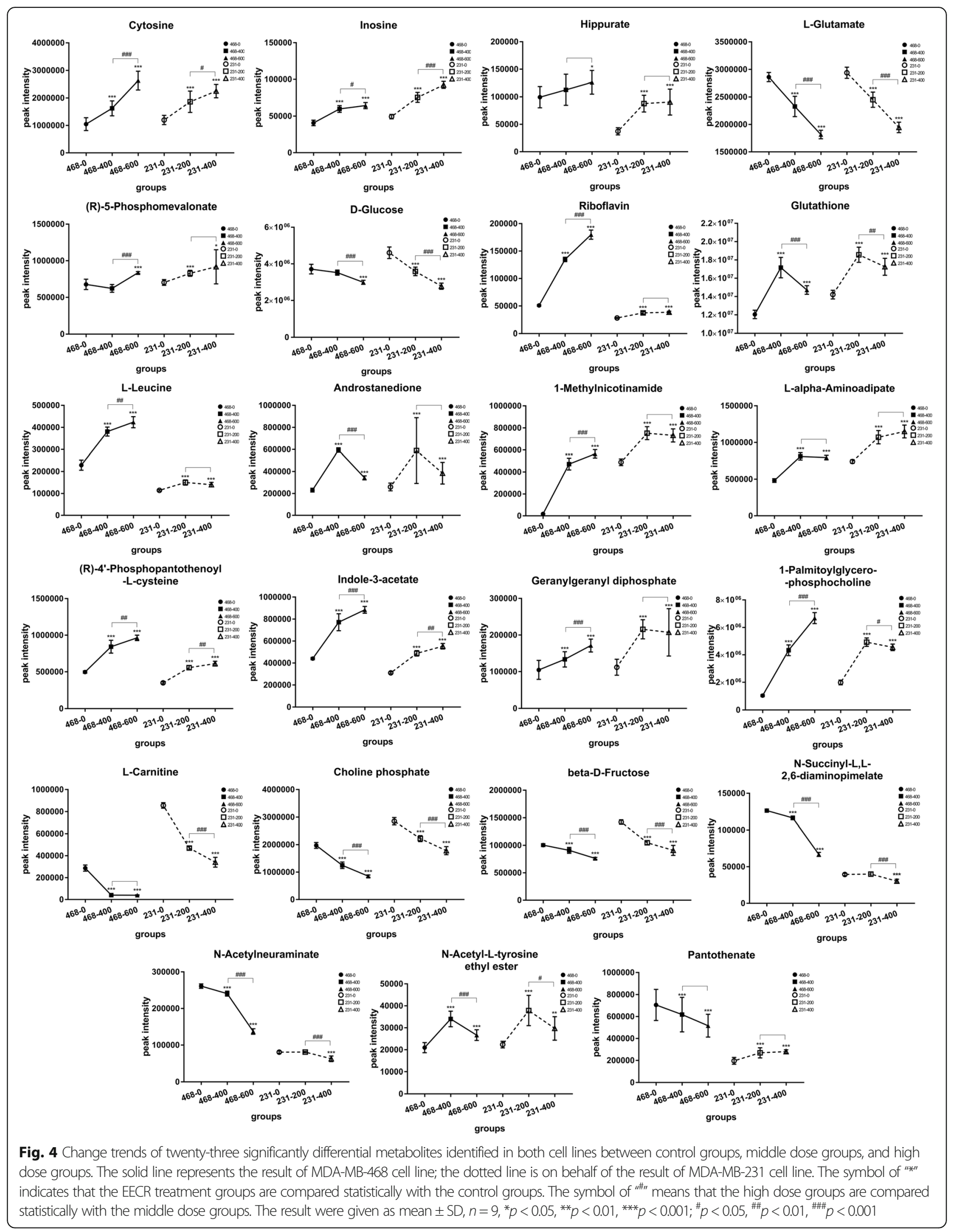




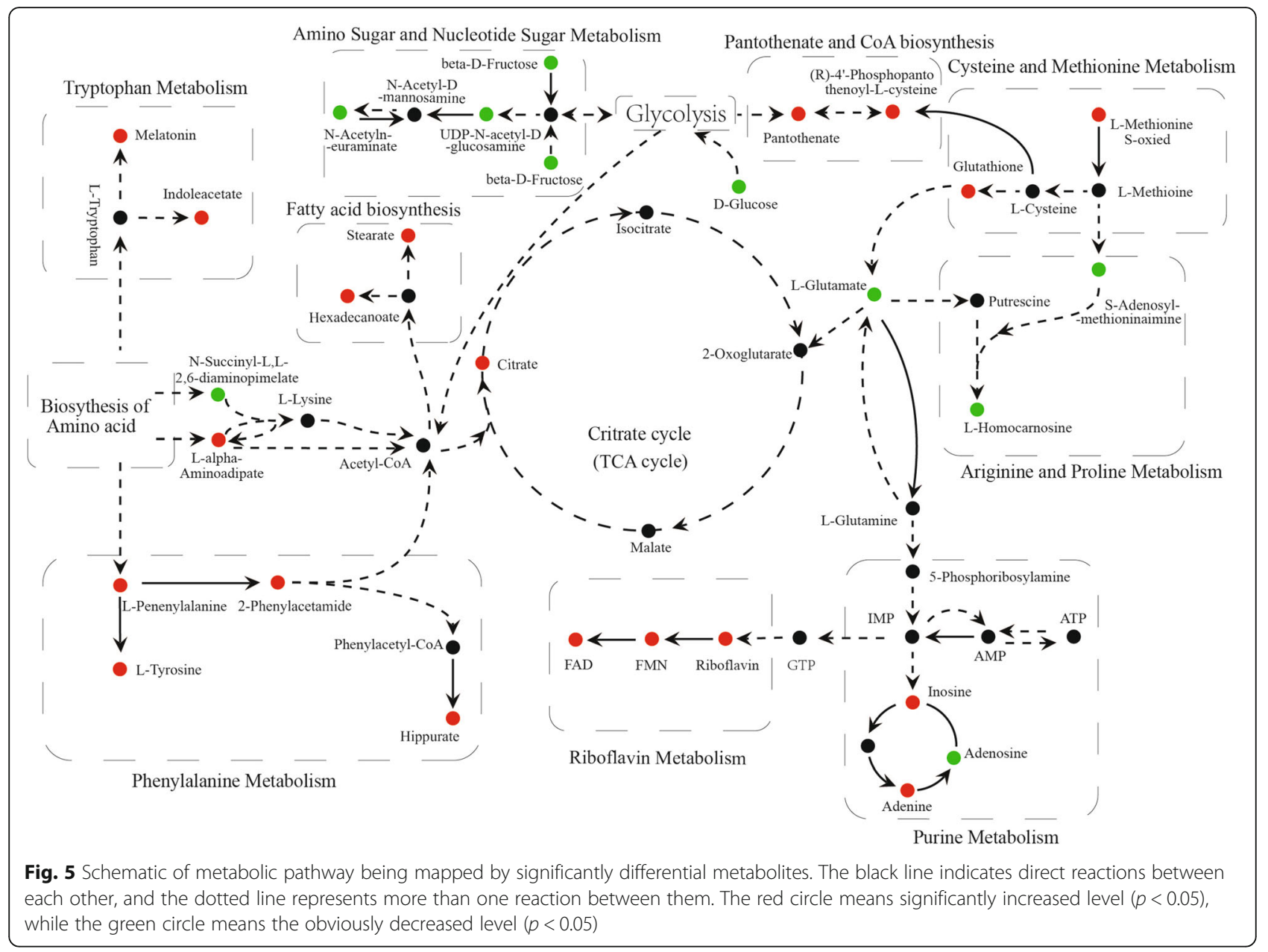

\section{Carbohydrate metabolism}

The fore-mentioned Carbohydrate metabolic processes, containing Central Carbon metabolism (TCA cycle) in cancer, Glycolysis, and Amino Sugar and Nucleotide Sugar metabolism, could provide energy for cell proliferation. The high level of citrate and the low level of glucose and L-glutamate were found in EECR treatment groups. Metabolites taking part in Amino Sugar and Nucleotide Sugar metabolism were up-regulated after EECR treatment.

A fundamental difference in the central metabolism exists between cancer cells with normal cells. In 1956, the German Nobel Prize winner Otto Warburg established that cancer cells consumed an abundance of glucose and maintained a high rate of glycolysis even under sufficient oxygen concentrations to support mitochondrial oxidative phosphorylation which was known as "aerobic glycolysis" [19-21]. Citrate, the first production of the TCA cycle, plays a negative feedback regulating role in glycolysis and TCA cycle itself. Citrate slows down or arrests these pathways, but it stimulates the ATP-consuming pathways. The lower level of glucose in EECR treatment groups exactly confirms that breast cancer cells have consumed too much glucose for producing energy compared to the control group. While the citrate at a high level slowed down the Glycolysis in negative feedback manner.

The citrate is not only a key regulator of energy production but an essential metabolic intermediary. It could activate acetyl-CoA carboxylase, the first enzyme for fatty acid synthesis, and provide abundantly Acetyl-CoA for the Fatty Acid biosynthesis [22]. The elevated levels of Stearate and Hexadecanoate participating in the Fatty Acid biosynthesis and benefiting from the activation of Citrate were detected in this study. As a consequence, the ATP consumption was increased.

The EECR acted on Carbohydrate metabolism, breaking the balance between ATP-production and ATPconsumption, resulting in severe energy depletion inside cells, leading to cell growth arrest and cell death.

\section{Riboflavin metabolism}

Riboflavin, as a biological precursor of FAD and FMN which serves as electron carriers for a range of redox reactions, participates in oxidation-reduction reactions 
in numerous metabolic pathways and in energy production via aerobic respiration [23-25]. Lack of riboflavin has been reported to be associated with an increased risk for malignant tumor [26]. The supplement of Riboflavin enhanced the aerobic respiration in mitochondria which might compete for more substrates and restrain the aerobic glycolysis to some extent [27-29]. After EECR treatment, the levels of Riboflavin and its active coenzymic molecules such as FAD and FMN were all significantly elevated. We suppose that EECR suppresses the aerobic glycolysis by inducing the Riboflavin metabolism to arrest cell proliferation.

\section{Amino acid metabolism}

All amino acids are valuable energy sources or precursors for the manufacture of other important substances. In this study, Amino acid metabolisms containing Phenylalanine metabolism, Cysteine and Methionine metabolism, Tryptophan metabolism, Lysine degradation, and Arginine and Proline metabolism were influenced by EECR. The levels of all significantly changed metabolites, which take part in Phenylalanine metabolism, Cysteine and Methionine metabolism, Tryptophan metabolism, or Lysine degradation, were up-regulated, whereas those participating in Arginine and Proline metabolism were down-regulated.

Abnormal Tryptophan metabolism is reported in a variety of cancers [30-33]. Serotonin and melatonin are two vital products of Tryptophan metabolism. The lowexpression of indoleacetate, a breakdown product of tryptophan metabolism, was also reported in breast cancer [31]. In this study, the treatment of EECR reversed the trend of indoleacetate which show a higher level in EECR treatment group. The mechanism of serotonin was extremely complex in breast cancers, which seems to transfer its tumor-suppressive actions into a tumorpromoting effect, accompanied by a significant increase in Serotonin synthesis [34, 35]. The therapies on the serotonin system will provide valuable therapeutic method for breast cancer. Melatonin is a downstream product of serotonin. And the reduction of melatonin has been reported in patients with malignant tumors [32]. Gamal H. et al. reported that melatonin prevented breast cancer metastasis through inhibiting DJ-1/KLF17/ ID-1 signaling pathway [36]. In this study, the level of melatonin was enhanced after the treatment of EECR. The significant increase of melatonin reversed the expression trend in malignant tumors. Although the specific mechanism is still unclear, we predict that the EECR acts on the serotonin system, in which it accelerated the transformation of serotonin to melatonin.

Phenylalanine and tyrosine both are the precursors of the catecholamines which is a kind of neurotransmitters acting as adrenalin-like substances. The alterations of genes related to Phenylalanine metabolism were reported in breast cancer tissue [37]. In this research, all significantly differential metabolites matched to the Phenylalanine metabolism were found at a higher level after the EECR treatment. Some reports suggested that a high concentration of phenylalanine and its metabolites cloud induce cell apoptosis [38, 39]. We suppose the apoptosis is related to the higher level of Phenylalanine and its downstream metabolites.

In addition, breast cancer cells were reported as methionine-dependent cell line, which means the low expression of methionine limited their proliferation [40]. S-adenosylhomocysteine and methionine were two critical products between the methionine cycle, the expressions of S-adenosylhomocysteine and methionine depend on each other. The low level of S-adenosylhomocysteine was found in this study reflecting a low concentration of methionine which indicated the limited proliferation of TNBC cells.

Glutathione, synthesized from three amino acids: glycine, glutamate, and cysteine, abundantly and widely distributes throughout different cell types. The high level of glutathione has a complicated role in both cancer and antineoplastic therapy which plays a vital role in the elimination of carcinogens while increases the resistance to cancer chemotherapeutic [41]. The remarkably lower level of Glutamate being a substance of glutathione was detected in this study. Consequently, the synthesis of glutathione could be feedback-inhibited by the short of Glutamate. Although further research is essential, we establish that EECR could decrease the level of Glutathione through glutathione cycle at last.

Glutamine, a product of glutamate, is a significant energy source in general and particularly for malignant cells and plays a vital role as a source of nitrogen for the synthesis of nucleotides [42]. In this research, the lower level of glutamine was predicted by lower level of glutamate. The Purine metabolites, a kind of Nucleotide metabolism, provide the necessary energy and cofactors to promote cell survival and proliferation. Owing to their glutamine addiction, depletion of glutamine may arrest the proliferation and induce the apoptosis of TNBC cells [43].

In addition to considering the specific function of each amino and its metabolites, the action of ATP-consumption of each amino acid metabolism was taken into account for the depletion of energy, resulted in TNBC cell apoptosis ultimately.

\section{Conclusion}

In this study, we applied cell metabolism to detect the function mechanism of EECR on TNBC and found forty-nine significant differential metabolites which mapped to Central Carbon metabolism in cancer, Glycolysis, Amino Sugar and Nucleotide Sugar metabolism, Phenylalanine metabolism, Arginine and Proline 
metabolism, Cysteine and Methionine metabolism, Tryptophan metabolism, Lysine degradation, Purine metabolism, Riboflavin metabolism, Pantothenate and CoA biosynthesis, and Fatty Acid biosynthesis.

Among these significant differential metabolites, twentythree were found in both two TNBC cell lines, and twenty two metabolites expressed the same change trend in content between control group, middle dose group, and high dose group, which explained the reason why the EECR induced apoptosis on TNBC cells with dose-dependent manner and confirmed the value of these metabolites in the process of EECR inducing TNBC apoptosis.

Through a systematic metabolism analysis, EECR impacted the energy metabolism of TNBC cells by arresting the pathways of Carbohydrate metabolism such as Central carbon metabolism in cancer, aerobic glycolysis, and Amino sugar and nucleotide sugar metabolism, whereas accelerating the pathways of ATP-consumption including Amino acids metabolism, Fatty acid metabolism, Riboflavin metabolism and Purine metabolism which broke the balance between ATP-production and ATP-consumption, resulted in severe ATP depletion inside cells, arrested the proliferation and induced the apoptosis of TNBC cells.

In conclusion, EECR induces apoptosis mainly by affecting the energy metabolism. This research reveals that EECR has great potential in the clinical treatment of TNBC with fewer toxic and side effects which need further study.

\section{Supplementary information}

Supplementary information accompanies this paper at https://doi.org/10. 1186/s12906-020-02981-w.

Additional file 1: Figure S1. The result of multivariate statistical analysis in negative mode. PCA score plot of MDA-MB-231 cells and MDA-MB-468 cell were showed in A and B. The green circle represents the control group respectively named $231-0$ or $468-0$; the blue box represents the middle dose group such as $231-200$ or 468-400; the red triangle means the high dose group name $231-400$ or 468-600. The EECR treatment groups were obviously distinct with the control groups through the PCA analysis (A, B). The PLS-DA was performed between the high dose group and the control group resulted in $R 2 X=0.421, R 2 Y=$ 0.994 , and Q2 $=0.942$ in MDA-MB-231 cells (C), and R2X $=0.432, \mathrm{R} 2 \mathrm{Y}=$ 0.995, and Q2 $=0.962$ in MDA-MB-468 cells (D). The permutation plot tests the Statistical validation of the PLS-DA model $(n=200)$ showing the values of R2 (green circle) and Q2 (blue box) (E, F).

\footnotetext{
Abbreviations

TNBC: Triple-negative breast cancer; EECR: The ethanol extract of Cyperus rotundus L; UPLC-Q-TOF-MS/MS: Ultra-high performance liquid chromatography coupled with quadrupole-time-of-flight mass spectrometry; ER: Estrogen receptor; PR: Progesterone receptor; Her-2: Human epidermal growth factor receptor-2; DMEM: Dulbecco's modified Eagle's medium; FBS: Fetal bovine serum; PBS: Phosphate-buffered saline; DMSO: Dimethyl sulfoxide; CCK-8: Cell Counting Kit-8 assay; OD: Optical density; PI: Propidium lodide; QC: Quality control; PCA: Principal component analysis; PLS-DA: Partial least squares discriminant analysis; FC: Fold Change; RSD: The relative standard deviation; BPCs: Base peak chromatograms; FAD: Flavin adenine dinucleotide; FMN: Riboflavin-5-phosphate
}

\section{Acknowledgments}

Not Applicable.

\section{Authors' contributions}

Conceptualization: FKW; Methodology: SSM; Formal analysis and investigation: SSM and FKW; Writing - original draft preparation: SSM and FKW; Writing - review and editing: XZW, XYW, ZYY and CJZ; Funding acquisition: $X Y W$ and $X Z W$; Resources: $Z Y Y$; Supervision: $X Y W$ and ZYY. All authors have read and approved the manuscript.

\section{Funding}

This study was funded by the Grants from the Natural Science Foundation of Shandong Province (ZR2019MH109 and ZR2017PH055), the Grant from the key research and development plan of Shandong Province (2016GSF201185), and special investigation on basic resources of science and technology (2018FY100704). Funds have been used in areas such as materials and experimentation.

\section{Availability of data and materials}

The datasets used and/or analysed during the current study available from the corresponding author on reasonable request.

\section{Ethics approval and consent to participate}

This article does not contain any studies with human participants or animals performed by any of the authors.

\section{Consent for publication}

All authors consent to publish this study in BMC Complementary and Alternative Medicine.

\section{Competing interests}

The authors have no competing interest.

\section{Author details}

${ }^{1}$ Shandong Cancer Hospital and Institute, Shandong First Medical University and Shandong Academy of Medical Sciences, No.440 jiyan road, Jinan 250017, Shandong, China. ${ }^{2}$ Shandong Hongjitang Pharmaceutical Group Co.,Ltd., Jinan 250000, China. ${ }^{3}$ School of life Science, Beijing University of Chinese Medicine, Northeast corner of intersection of Sunshine South Street and Baiyang East Road, Fang-Shan District, Beijing 102488, China. ${ }^{4}$ School of Chinese Materia Medical, Beijing University of Chinese Medicine, No.11 North 3rd Ring East Road, Chao-Yang District, Beijing 100029, China.

Received: 31 December 2019 Accepted: 1 June 2020

Published online: 26 August 2020

\section{References}

1. Schneider BP, Winer EP, Foulkes WD, Judy G, Perou CM, Andrea R, Sledge GW, Carey LA. Triple-negative breast cancer: risk factors to potential targets. Clin Cancer Res. 2008;14(24):8010.

2. Foulkes WD, Smith IE, Reisfilho JS. Triple-negative breast Cancer - NEJM; 2010

3. Narod SA. Breast cancer in young women. Nat Rev Clin Oncol. 2012;9(8): 460-70

4. Young SR, Pilarski RT, Donenberg T, Shapiro C, Hammond LS, Miller J, Brooks KA, Cohen S, Tenenholz B, Desai D. The prevalence of BRCA mutations among young women with triple-negative breast cancer. BMC Cancer. 2009;9(1):86

5. Bowen RL, Duffy SW, Ryan DA, Hart IR, Jones JL. Early onset of breast cancer in a group of British black women. Br J Cancer. 2008;98(8):1482 author reply 1483 .

6. Suryavanshi S, Choudhari A, Raina P, Kaul-Ghanekar R. A polyherbal formulation, HC9 regulated cell growth and expression of cell cycle and chromatin modulatory proteins in breast cancer cell lines. J Ethnopharmacol. 2019;242:10.

7. Park SE, Shin WT, Park C, Hong SH, Kim GY, Kim SO, Ryu CH, Hong SH, Choi $\mathrm{YH}$. Induction of apoptosis in MDA-MB-231 human breast carcinoma cells with an ethanol extract of Cyperus rotundus L. by activating caspases. Oncol Rep. 2014;32(6):2461-70.

8. Mannarreddy P, Denis M, Munireddy D, Pandurangan $R$, Thangavelu KP, Venkatesan K. Cytotoxic effect of Cyperus rotundus rhizome extract on human cancer cell lines. Biomed Pharmacother. 2017;95:1375-87. 
9. Pirzada AM, Ali HH, Naeem M, Latif M, Bukhari AH, Tanveer A. Cyperus rotundus L.: traditional uses, phytochemistry, and pharmacological activities. J Ethnopharmacol. 2015;174:540-60.

10. Wang FK, Song $X$, Ma SS, Liu CY, Sun XH, Wang XZ, Liu ZY, Liang D, Yu ZY. The treatment role of Cyperus rotundus $L$ to triple-negative breast cancer cells. Biosci Rep. 2019:39:12.

11. Patti GJ, Yanes O, Siuzdak G. Metabolomics: the apogee of the omic triology. Nat Rev Mol Cell Biol. 2013;13(4):263.

12. Peterson AL, Walker AK, Sloan EK, Creek DJ. Optimized method for untargeted metabolomics analysis of MDA-MB-231 breast Cancer cells. Metabolites. 2016;6(4):16.

13. Hounoum BM, Blasco H, Emond P, Mavel S. Liquid chromatography-highresolution mass spectrometry-based cell metabolomics: experimental design, recommendations, and applications. Trac-Trends Anal Chem. 2016; 75:118-28.

14. Hayton S, Maker GL, Mullaney I, Trengove RD. Experimental design and reporting standards for metabolomics studies of mammalian cell lines. Cell Mol Life Sci. 2017;74(24):4421-41

15. Sangster T, Major H, Plumb R, Wilson AJ, Wilson ID. A pragmatic and readily implemented quality control strategy for HPLC-MS and GC-MS-based metabonomic analysis. Analyst. 2006;131(10):1075-8.

16. Roberts LS, Yan P, Bateman LA, Nomura DK. Mapping novel metabolic nodes targeted by anti-Cancer drugs that impair triple-negative breast Cancer pathogenicity. ACS Chem Biol. 2017;12(4):1133-40.

17. Dyczynski M, Vesterlund M, Bjorklund AC, Zachariadis V, Janssen J, GallartAyala H, Daskalaki E, Wheelock CE, Lehtio J, Grander D, et al. Metabolic reprogramming of acute lymphoblastic leukemia cells in response to glucocorticoid treatment. Cell Death Dis. 2018;9:13.

18. Zelena E, Dunn WB, Broadhurst D, Francis-McIntyre S, Carroll KM, Begley P, O'Hagan S, Knowles JD, Halsall A, Wilson ID, et al. Development of a robust and repeatable UPLC-MS method for the Long-term Metabolomic study of human serum. Anal Chem. 2009:81(4):1357-64.

19. Heiden MGV, Cantley LC, Thompson CB. Understanding the Warburg effect: the metabolic requirements of cell proliferation. Science. 2009;324(5930): 1029-33.

20. Koppenol WH, Bounds PL, Dang CV. Otto Warburg's contributions to current concepts of cancer metabolism. Nat Rev Cancer. 2011;11(5):325-37.

21. Chen JQ, Russo J. Dysregulation of glucose transport, glycolysis, TCA cycle and glutaminolysis by oncogenes and tumor suppressors in cancer cells. Biochim Biophys Acta-Rev Cancer. 2012;1826(2):370-84.

22. Icard P, Poulain L, Lincet $H$. Understanding the central role of citrate in the metabolism of cancer cells. Biochim Biophys Acta-Rev Cancer. 2012; 1825(1):111-6

23. Saravana Perumal S, Shanthi P, Sachdanandam P. Energy-modulating vitamins - a new combinatorial therapy prevents cancer cachexia in rat mammary carcinoma. Br J Nutr. 2005;93(6):901-9.

24. Henriques BJ, Lucas TG, Gomes CM. Therapeutic approaches using riboflavin in mitochondrial energy metabolism disorders. Curr Drug Targets. 2016; 17(13):1527-34.

25. Ozsvari B, Bonuccelli G, Sanchez-Alvarez R, Foster R, Sotgia F, Lisanti MP. Targeting flavin-containing enzymes eliminates cancer stem cells (CSCs), by inhibiting mitochondrial respiration: vitamin B2 (riboflavin) in cancer therapy. Aging-US. 2017:9(12):2610-28.

26. Long L, He JZ, Chen Y, Xu XE, Liao LD, Xie YM, Li EM, Xu LY. Riboflavin depletion promotes tumorigenesis in HEK293T and NIH3T3 cells by sustaining cell proliferation and regulating cell cycle-related gene transcription. J Nutr. 2018;148(6):834-43.

27. Khan NA, Teli MA, Mohib-ul Haq M, Bhat GM, Lone MM, Afroz F. A survey of risk factors in carcinoma esophagus in the valley of Kashmir, Northern India. J Canc Res Ther. 2011;7(1):15-8

28. Zou XN, Taylor PR, Mark SD, Chao A, Wang W, Dawsey SM, Wu YP, Qiao YL, Zheng SF. Seasonal variation of food consumption and selected nutrient intake,in Linxian, a high risk area for esophageal cancer in China. Int J Vitam Nutr Res. 2002;72(6):375-82.

29. Siassi F, Ghadirian P. Riboflavin deficiency and esophageal cancer: a case control-household study in the Caspian Littoral of Iran. Cancer Detect Prev. 2005;29(5):464-9.

30. Michelhaugh SK, Muzik O, Guastella AR, Klinger NV, Polin LA, Cai H, Xin Y, Mangner TJ, Zhang S, Juha C. Assessment of tryptophan uptake and kinetics using 1-(2-F-18-Fluoroethyl)-L-tryptophan and alpha-C-11-methyl-L- tryptophan PET imaging in mice implanted with patient-derived brain tumor Xenografts. J Nucl Med. 2017;58(2):208-13.

31. Jasbi P, Wang DF, Cheng SL, Fei Q, Cui JY, Liu L, Wei YP, Raftery D, Gu HW. Breast cancer detection using targeted plasma metabolomics. J Chromatogr B. 2019;1105:26-37.

32. Bartsch $\mathrm{C}$, Bartsch $\mathrm{H}$. Melatonin in cancer patients and in tumor-bearing animals. Adv Exp Med Biol. 1999:467:247-64.

33. Juhasz C, Nahleh Z, Zitron I, Chugani DC, Janabi MZ, Bandyopadhyay S, AliFehmi R, Mangner TJ, Chakraborty PK, Mittal S, et al. Tryptophan metabolism in breast cancers: molecular imaging and immunohistochemistry studies. Nucl Med Biol. 2012:39(7):926-32.

34. Pai V, Marshall A, Hernandez L, Horseman N. Abstract \#3365: serotonin a novel marker for breast cancer: bimodal association with breast cancer progression. Cancer Res. 2009;69(9 Supplement):3365.

35. Leoncikas V, Wu HH, Ward LT, Kierzek AM, Plant NJ. Generation of 2,000 breast cancer metabolic landscapes reveals a poor prognosis group with active serotonin production. Sci Rep. 2016:6:13.

36. El-Sokkary GH, Ismail IA, Saber SH. Melatonin inhibits breast cancer cell invasion through modulating DJ-1/KLF17/ID-1 signaling pathway. J Cell Biochem. 2019:120(3):3945-57.

37. Akkiprik M, Peker I, Ozmen T, Amuran GG, Gulluoglu BM, Kaya H, Ozer A. Identification of differentially expressed IGFBP5-related genes in breast Cancer tumor tissues using cDNA microarray experiments. Genes. 2015;6(4): 1201-14.

38. Yongjun Z, Xuefan G, Xiaobing Y. Phenylalanine activates the mitochondriamediated apoptosis through the RhoA/rho-associated kinase pathway in cortical neurons. Eur J Neurosci. 2010;25(5):1341-8.

39. Ali MR, Wu Y, Han T, Zang X, Xiao H, Tang Y, Wu R, Fernandez FM, El-Sayed MA. Simultaneous Time-dependent Surface Enhanced Raman Spectroscopy, Metabolomics and Proteomics Reveal Cancer Cell Death Mechanisms Associated with Au-Nanorod Photo-thermal Therapy. J Am Chem Soc. 2016; 138(47):jacs.6b08787.

40. Lien EC, Ghisolfi L, Geck RC, Asara JM, Toker A. Oncogenic PI3K promotes methionine dependency in breast cancer cells through the cystineglutamate antiporter xCT. Sci Signal. 2017;10(510):13.

41. Balendiran GK, Dabur R, Fraser D. The role of glutathione in cancer. Cell Biochem Funct. 2004:22(6):343-52.

42. Liu XY, Fu YM, Meadows GG. Differential effects of specific amino acid restriction on glucose metabolism, reduction/oxidation status and mitochondrial damage in DU145 and PC3 prostate cancer cells. Oncol Lett. 2011;2(2):349-55.

43. Yang LF, Moss T, Mangala LS, Marini J, Zhao HY, Wahlig S, Armaiz-Pena G, Jiang DH, Achreja A, Win J, et al. Metabolic shifts toward glutamine regulate tumor growth, invasion and bioenergetics in ovarian cancer. Mol Syst Biol. 2014;10(5):23

\section{Publisher's Note}

Springer Nature remains neutral with regard to jurisdictional claims in published maps and institutional affiliations.

Ready to submit your research? Choose BMC and benefit from:

- fast, convenient online submission

- thorough peer review by experienced researchers in your field

- rapid publication on acceptance

- support for research data, including large and complex data types

- gold Open Access which fosters wider collaboration and increased citations

- maximum visibility for your research: over $100 \mathrm{M}$ website views per year

At BMC, research is always in progress.

Learn more biomedcentral.com/submission 